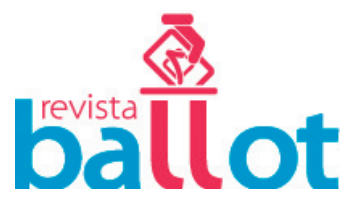

\title{
The new challenges against corruption. The response of the Brazilian Juridical System
}

\author{
Vicenzo Laruffa (Pontificial Lateran University, Itália) \\ enzo.laruffa@gmail.com \\ Piazza San Giovanni in Laterano, 4, \\ 00184 Città del Vaticano, Cidade do Vaticano
}




\begin{abstract}
This paper will discuss and evaluate the question of the study of all those offenses relating to corruption, with particular reference to the legislation in force in two geographically distant systems to each other, but legally similar and undergoing major changes and amendments by national parliaments; it refers to the Italian legal system and the Brazilian legal system.

First, we will discuss the issue of the anti-corruption legislation in Italy, with reference to the new legislation, Law no. 69/2015, which restates the strategy of prevention and criminal repression of the phenomenon of corruption and criminal offenses against the public administration.

In fact, this new law has increased the penalties and has expanded the number of persons prosecuted under law for criminal liability.

Secondly, the other hand, there is need to review the legislation currently in force in Brazil, in recent years subject to changes that increasingly are an expression of fundamental constitutional principles such as "transparency of public administration"," political responsibility", "the good performance and efficiency in the exercise of the public interest". Another important factor in the Brazilian system is the enhancement of control activities, rather than political-criminal prevention of the crime of corruption. They are all the elements were analyzed that highlight the similarities and differences of two very different legal systems, but which tend, maybe in the future, to comply against these crimes.
\end{abstract}

Keywords $¥$ trasparency; prevention; law harmonization

\title{
Os novos desafios no combate à corrupção. A resposta do sistema judiciário brasileiro
}

\section{Resumo}

Este trabalho irá discutir e avaliar crimes relacionados a corrupção, com atenção especial à legislação vigente em dois sistemas jurídicos geograficamente distantes entre si, mas legalmente similares. Estes sistemas estão atravessando grandes mudanças, passando por reformas realizadas por seus parlamentos nacionais. São eles os sistemas legais Italiano e brasileiro.

Primeiramente, iremos discutir a questão da legislação anticorrupção na Itália, fazendo referencia à nova Lei n ${ }^{\circ} 69 / 2015$, que reformula a estratégia de prevenção e repressão criminal do fenômeno da corrupção de crimes contra a administração pública. De fato, essa nova lei aumentou as penas e expandiu o número de pessoas processadas por responsabilidade criminal.

Em seguida, há a necessidade de analisar a legislação vigente no Brasil, objeto de alterações recentes que cada vez mais se mostram como expressóes de princípios constitucionais como os da "transparência da administração pública", "responsabilidade política", "eficiência e exercício do interesse público". Outro fator importante no sistema brasileiro é o incremento das atividades de controle ao invés da prevenção político-criminal do crime de corrupção.

Esses são os elementos a serem analisados que apontam as semelhanças e diferenças de dois sistemas legais muito diferentes, mas tendentes, futuramente, a uma provável aproximação no que diz respeito ao combate à corrupção.

Palavras-chaveः transparência; prevenção; uniformização do direito 


\section{How can we define the crime of corruption?}

One of the most important definitions of the crime of corruption is an exchange of services between a person who does an illegal act (abuse of authority) for the benefit of another person that in exchange corresponds to it money or other assets. Moreover, according to this definition, the legal systems distinguish the crime of corruption in different subspecies, that we discuss later in the text.

\section{A comparison between different legal systems The Italian experience}

The original anti-corruption legislation in force in Italy has always been characterized by strong repression of the events of corruption; sometimes with very harsh penalties detention.

In 2012, following the results of the surveys related to the spread of the corruption phenomenon, the Italian parliament has decided to reform the corruption matter by applying the law n. 6 November 2012. This law it strengthened existing legislation and has renewed the system of prevention of crime, expanding the categories of persons who could be punished as responsible for corruption.

The need to take action on the existing legislation, to reform the crimes against the public administration, is the result of some important international events, including:

a) in 2012 the ratification of the Criminal Law Convention on Corruption (Council of Europe -1999);

b) in 2009 the UN Convention on Corruption (2003).

Is also necessary to consider the number of international meetings that were held between the delegates of the OECD, which led to the development of various proposals to promote a more effective prevention of corruption (such as the development of systems of measurement of corruption, management of Public Administration through models based on risk management. Determined has been the famous Greek Report (Group of States against corruption) who modified the existing legal system in 2012, and finally, also the negative data recorded by the rating system of control of corruption, who have located Italy one of the last places in the European ranking, with a trend that, unfortunately, may get worse.

With the law of n. 190 of November 2012, entitled "Measures for the prevention and suppression of corruption and illegality in public administration", the Italian legislature acted primarily on crime of extortion (art. $317 \mathrm{cp}$ ), limiting the punishment of the crime only in hypothesis of extortion for "constraint", and also provided for the first time the case of the crime of extortion for "induction", as a new offense (punishable by punishments less restrictive, art. 319 of Penal Code).

In terms of criminal prosecution, the new anti-corruption law has modified the original sanction, which provided a minimum of four years in prison by increasing this one until a minimum of six years, while the maximum penalty has remained unchanged to twelve years in prison.

About the new offenses recently introduced in the Italian criminal system, deserves to be remembered the new crime of "inducing undue". In this case, the law, contrary to what was done with the first corruption law, punishes both the public official and the person who practices public functions, although not being a public official. 
Therefore, the crime in question punishes any public official who, abusing his powers induces another person unlawfully to pay or promise to himself money or other property. The innovative element that the Italian legislature has wanted to reach - based on the recommendations of the international community - was to avoid the creation of a state of impunity of the private citizen ${ }^{83}$.

In fact, the person induced to give or promise money or other benefits is no longer considered a victim (contrary to what happens in the case of the robbery where you need the element of coercion). Instead, the only responsible is the public official, because it has not been subjected to a constricting behavior, but a simple conviction that he could have oppose.

Regarding the reform of the criminal offense of corruption (art. 318 and 319 of the Criminal Code), we report that was eliminated the possibility of the so-called corruption "improper", which was replaced by the new offense of "corruption in the exercise of function ". This new subspecies of the crime of corruption provides that "the public official who, in the exercise of its functions and powers, receives improper money or other property shall be punished with imprisonment from one up to five years".

For a complete and updated vision of what is now the Italian system, in relation to anticorruption legislation, it is necessary to dwell on the latest modification in the matter, the law n. 69/2015, better known as the anti-corruption law.

This law, in fact, does not present a new strategy for the prevention and repression of corruption and other crimes against the public administration, but is limited to increase - as had happened previously with the reform of 2012 - the sanctions and a expansion of the category of those responsible for these crimes.

To conclude, the current anti-corruption legal system in force in Italy is characterized by the presence of three different offenses: bribery, embezzlement and extortion with induction, which together with each other represent the policy of repression of the crimes against the public administration ${ }^{84}$.

To complete the examination of Italian legal system, especially regarding the contrast of illegality, should highlight further remedies used in both administrative and criminal law, those that are usually called "interdiction measures".

In particular, the reference is to ineligibility and incompatibility institutes, these institutions shall apply those who have been convicted for crimes against the public administration.

Precisely, it is in this context that the regulation of candidates for public office and political, national and local, are met (or better, interacts) with anti-corruption criminal legislation ${ }^{85}$.

In fact, the Law 190/2012, which was the first law with this objective, provided that for the purposes of preventing and combating corruption, the convicted person for crimes against the public administration (arts. 314-335 cp), not can carry out public executive positions or executive positions at subject to public control of private-sector entities (even if the sentence has been issued with a no final judgment $)^{86}$.

83. Although it has been provided for the realization of the crime. Therefore, it is criminally responsible.

84. Before the European influences, the Italian criminal law does not punish the private citizen, because it was considered a victim of "induction undue", in fact the induction implicates a constriction of the will of others people and for this reason cannot be punished.

85. in addition to corruption, refer to many other crimes, such as: money laundering, receiving stolen goods, abuse of power, embezzlement, criminal association, etc.

86. Cfr. Legge 27 marzo 2001, n. 97, art. 3, comma 1, lett. a. 
Those convicted is also prohibited to be assigned to offices who deal with management of financial resources, acquisition of goods, supplies of services, subsidized or other activity are given financial benefits to subjects, both public and private ${ }^{87}$.

The Law 190/2012 was followed by a new legislation about incompatible with a executive positions in public administrations, is the D.lgs. April 8, 2013, n. 39, which came into force May 4, $2013^{88}$.

The rules governing of Legislative D. lgs. N. 39/2013 is based on the identification of incompatibility situations of a wide series of administrative tasks (art. 3 to 8 ) and on the identification incompatibility situation between different tasks (art. 9 to 14).

The heart of the new legislation is the need to ensure the impartiality of public functions, in full transparency and in the public interest.

The first articles of the new law are devoted to those causes that prohibit the assignment of tasks, permanent or temporary, for those who: 1) have had criminal sentences for crimes under artt. 314-335 c.p ; 2) in the previous two years they have held positions in private companies, managed by the Public Administration; 3 ) in the previous two years they have been members of political bodies.

The new law confirms the previously planned system of sanctions and in some cases introduces important changes, such as the ability to exclude permanently from carrying out certain tasks those who have committed particularly serious crimes against the public administration.

Another interesting innovation applied by the new law was the initiative to publish a list with the names of all those who due to incompatibility, cannot carry out public or political roles.

In order to achieve more concrete output would be necessary conceived more restrictive provisions, providing for the immediate ineligibility at the sentencing for a particular type of crime, regardless of the sentence imposed ${ }^{89}$.

\section{The case of Brasil}

The decision to examine the legal system in Brazil, and in particular its specific strategy of repression of corruption and of all the crimes against the public administration, comes from two aspects: the first because both Brazil and Italy are linked by the long legal tradition of civil law, while the second because the laws applied in Brazil make up one of the few systems in the world that is showing positive results against corruption (along with Italian laws in recent application). Brazil is the country with the largest land mass, the high density of population, as well as the richest natural resources in South America. This is enough to accept that Brazil is one of the first countries in South American that can affect the economic life of the entire continent.

87. Cfr. Legge 27 marzo 2001, n. 97, art. 3, comma 1 lett. b.

88. Cfr. CORRADO, Il legislatore predispone regole a valenza generale per far emergere situazioni di conflitto d'interesse, in Guida Dir., 2013, n. 20, 38 ss.

89. Moreover, for some industry regulations are envisaged similar restrictions (see, for example, Art. $10 \mathrm{DM}$ 28 April 1998, n. 406, on the subject of registration in the companies engaged in the collection and transport of garbage (Leg. February 5, 1997, n. 22). 
For these reasons, Brazil is among the countries most exposed to social problems such as corruption and therefore needs a special control and more careful management of the public interest. In fact, the phenomenon of corruption is often the cause of serious damage that can affect the political, economic and cultural development of a society that unfortunately, pursues only the economic human interest, the only personal enrichment, forgetting a much deeper reality that underlies of a healthy society, the public ethics.

However, Brazil, precisely to encourage the application of the fundamental principle of public ethics, has launched a new policy of consolidation of public finances based on a new economic planning and greater fiscal control.

There was a important work on reforming of the national economic system that also involved the legal criminal system, which has changed considerably, characterized primarily on raising of penalties already in force, and also on the application of new instruments for preventing corruption and all other crimes such as financing of terrorism and money laundering that (similarly of the crime of corruption) are economic crimes that damage the structures of the public administration and social balance.

The main objective followed by the legislature in Brazil was not just the reform of professional codes of ethics, but rather to ensure a high level of transparency of public administration, in order to promote high standards of conduct of public officials. Before examining the anti-corruption legislation in force, it is necessary to consider briefly on the sources of law in the Constitution of Brazil.

In fact, the Constitution of Brazil (in the same way any other state constitution) has the task of regulating the protection of general principles, such as: public ethics, legality, efficiency, fairness, good economic performance, etc; these are fundamental elements of European derivation and are placed as fundamental principles in the public administration.

Indeed, Article 37, paragraph 4 of the Constitution of Brazil provides that: "Acts of administrative dishonesty shall result in the suspension of political rights, loss of public function, prohibition to transfer personal property and reimbursement to the public treasury, in the manner and grading established by law, without prejudice to the applicable criminal action". The Constitution of Brazil specifies the duty of the government to respect the principles of impartiality and efficiency, and requires all public authorities to apply public procedures in the sectors of the public work, services, purchases and sales. From this brief examination of the constitutional order, one understands the broad attention given by the Constitution to the matter of public administration and to tools for ensuring the care and the efficiency of public interests.

However, although in the last years, there have been many new rules to improve the anti-corruption system; the most effective instrument of prevention is the administrative and accounting control of the activities performed by institutions that have a public role.

This activity of "control" of the accounting and administrative operations, is performed considering the parameters of economy and efficiency dictated by the main auditors: the most important of all is the Federal Audit Court. (It is an auxiliary organ compared to National Congress).

The exercise of the function of administrative and financial control is governed by Title IX of the Constitution in Article 71, which provides that this type of control is carried out for the reports of managers and other responsible for of money or public assets.

As for the repression and prevention of corruption through penal sanctions, the Brazilian legal system had already provided in the Criminal Code of 1940, the crimes (called "crimes against the public administration") against corruption. These crimes were divided into two 
different categories: 1 . crimes committed by public officials, such as: the embezzlement, the insertion of false information into the computer system, the corruption and the abuse of power; 2. crimes against the public administration in general, such as: bribery, fraud market, the subtraction of documents, etc.

These criminal offenses have not been amended after an extensive process of reforms undertaken in recent years. However, these reforms were largely focused primarily on the matter of international financial fraud and do not concern the internal corruption and ethics in public administration offices.

The new laws, the most recent being the Law 10,467 / 2002 that has regulated the new types of criminal responsibility for cases of passive corruption.

More interesting, however, are the instruments of governance applied within the public administration offices to prevent corruption cases, in particular: the Office of the Comptroller General of the Union and the Commission for Public Ethics ${ }^{90}$.

The legislative intervention of renewal of the anti-corruption policy, ended on international level. In fact, after having widely reformed the Constitution and the legal structure of the legal criminal system, the State of Brazil has been able to sign and ratify four main international conventions related to Combating Corruption: the OECD Convention against Corruption, the UN Convention against Corruption (UNCAC), the Inter-American Convention against Corruption and the UN Convention against Transnational Organized Crime.

To conclude, describing the actual situation existing today, the Brazilian legislator has recently added a series of laws Which have integrated the policy against corruption in Brazil, in fact: in October 2011, the Congress approved a law on freedom of information on public That spending greatly expanded the transparency obligations of public administrations in respect of citizens; while, in July 2012 another law has established direct responsibility of legal persons for acts of corruption committed against the public administration, such as corruption of public officers.

90. The Brazil does not have a real anti-corruption authorities, such as the one established in Italy in the last few years (ANAC), but in 2003, has been set up a national agency against corruption and money laundering (ENCCLA - Estrategia Nacional de Combate à Corrupção and à Lavagem de Dinheiro). The last important element that characterizes the strategy against corruption in Brazil is the National Programme of Development of Vocational against money laundering (PNLD), a program aimed at training of public officials on the meaning of corruption and money laundering and the negative consequences of these criminal activities. 
Recebido em: $12 / 03 / 2016$

Aceito em: 28/03/2016

\section{Como citar}

LARUFFA, Vicenzo. The new challenges against corruption: the response of the Brazilian Juridical System. Ballot. Rio de Janeiro: UERJ. Volume 2 Número 1 Janeiro/Abril 2016. pp. 55-62. Disponível em: [http://www.e-publicacoes.uerj.br/index.php/ballot]

\section{(c) (1)(0)}

A Revista Ballot está licenciada sob uma licença Creative Commons Atribuição - Não Comercial - Compartilha Igual 3.0 Não Adaptada. 